\title{
Familial versus Sporadic Essential Tremor: What Patterns Can One Decipher in Age of Onset?
}

\author{
Elan D. Louis ${ }^{a, b}$ Lorraine N. Clark ${ }^{c, d}$ Ruth Ottman ${ }^{\text {e-h }}$ \\ ${ }^{a}$ Department of Neurology, Yale School of Medicine, ${ }^{b}$ Department of Chronic Disease Epidemiology, Yale School of \\ Public Health, Yale University, New Haven, Conn., 'Taub Institute for Research on Alzheimer's Disease and the Aging \\ Brain, College of Physicians and Surgeons, Columbia University, ${ }^{\mathrm{d}}$ Department of Pathology and Cell Biology, Columbia \\ University Medical Center and the New York Presbyterian Hospital, ${ }^{e} \mathrm{GH}$ Sergievsky Center, ${ }^{\mathrm{f}}$ Department of Neurology, \\ College of Physicians and Surgeons, ${ }^{9}$ Department of Epidemiology, Mailman School of Public Health, Columbia \\ University, and hivision of Epidemiology, New York State Psychiatric Institute, New York, N.Y., USA
}

\section{Key Words}

Essential tremor · Epidemiology · Genetics · Familial · Sporadic . Age of onset

\section{Abstract \\ Background: Essential tremor (ET) is a very prevalent neuro- logical disease. Although familial and sporadic ET cases are assumed to have different age at onset distributions, no de- tailed study of this question has been carried out. Methods: Using a carefully characterized sample of 376 ET cases (232 (61.7\%) familial) enrolled in a clinical-epidemiological study, we contrasted the age of onset distributions in familial ver- sus sporadic ET. Results: Familial ET had a lower age at onset distribution, regardless of the current age. The majority (71 (86.6\%) of 82) of ET cases that appeared during childhood were familial rather than sporadic. Additionally, the onset of ET occurred after age 40 in a majority of cases (125 (53.9\%) of 232 with familial ET and 118 (81.9\%) of 144 with sporadic ET), and in approximately one-quarter to one-half of cases, after age 60 . Conclusions: The age of onset of ET differs be- tween familial and sporadic ET and furthermore, is variable}

within each of these groups. The onset of ET during childhood is usually familial, and the small number of identified exceptions could be due to de novo mutations. Understanding the heterogeneity in onset age will provide insights into the nature of underlying etiological and patho-biological processes about which little is presently known.

(C) 2015 S. Karger AG, Basel

\section{Introduction}

Although essential tremor (ET) is highly heritable [1$4]$, numerous ET cases do not have an identified family history $[1,2]$. This observation, with many others, indicates that environmental factors are also likely to play a role in the etiology of this disease [5-9]. Surprisingly, few if any clinical differences between familial and sporadic ET have been identified. One possible exception is age at onset: the two forms of ET are commonly assumed to differ with respect to age of onset, with earlier onset in the familial than in the sporadic form [10-12]. However, no detailed study has been carried out regarding the age of

\section{KARGER 125}

(c) 2015 S. Karger AG, Base

$0251-5350 / 15 / 0443-0166 \$ 39.50 / 0$
Elan D. Louis, MD, MSc

Department of Neurology, LCI 710

15 York Street, PO Box 208018

New Haven, CT 06520-8018 (USA)

E-Mail elan.louis@yale.edu 
onset distributions in the familial versus sporadic ET. Using a carefully characterized sample of nearly 400 ET cases enrolled in a clinical epidemiological study, we contrasted the distributions of age of onset in familial versus sporadic ET, to identify distinct patterns of age at onset. Understanding the heterogeneity in age at onset will provide insights into the nature of the underlying etiological and patho-biological processes, about which so little is presently known.

\section{Methods}

\section{Participants}

ET cases were enrolled in a study of environmental risk factors for ET at Columbia University Medical Center (CUMC) [13]. Hence, they were not enrolled based on the presence versus absence of family history of ET. Upon enrollment, a trained tester obtained written informed consent, approved by the CUMC Institutional Review Board, from all participants. ET cases were identified from two primary sources: a computerized billing database of all ET patients who were seen at least once at the Center for Parkinson's Disease and Other Movement Disorders at CUMC over the past 5 years, and the International Essential Tremor Foundation (IETF) [13]. IETF members who lived in the New York metropolitan area were mailed advertisements and volunteered as participants $[13,14]$. All enrollees had received diagnoses of ET from their treating neurologists and lived within a 2-hour driving distance of CUMC $[13,14]$. After enrollment, all diagnoses were confirmed using published diagnostic criteria, as outlined below $[13,14]$.

\section{Clinical Evaluation}

Each case underwent an in-person evaluation that included a series of demographic and clinical questionnaires. Age at onset was defined as the self-reported age at which the individual first noted tremor. A prior study indicated that this age is reliably reported by ET cases [15]. Each patient was asked whether he or she had one or more relatives with ET or tremor and, if so, to provide additional demographic and clinical information on each affected relative.

Each case also underwent a 20-minute videotaped neurological examination, which included an assessment of postural tremor, five tests of kinetic tremor, and assessments of head (neck), voice and jaw tremors [13]. Each videotaped examination was reviewed by E.D.L., who rated the severity of postural and kinetic arm tremors (range $0-3$ ) using a reliable and valid clinical rating scale, assigning a total tremor score (range 0-36) [13]. Diagnoses of ET were reconfirmed by E.D.L. based on the available data using Washington Heights Inwood Genetic Study of Essential Tremor (WHIGET) criteria (moderate or greater amplitude kinetic tremor (tremor rating $\geq 2$ ) during three or more tests or a head tremor, in the absence of Parkinson's disease, dystonia or another cause) [13]. These diagnostic criteria for ET were developed for a populationbased genetic study and, based on data from approximately 2,000 normal (non-diseased controls), the criteria carefully specify the specific examination maneuvers during which tremor should be

Familial versus Sporadic ET: Patterns in Age of Onset
Table 1. Demographic and clinical features of 376 ET cases

\begin{tabular}{lccc}
\hline $\begin{array}{l}\text { Demographic and } \\
\text { clinical features }\end{array}$ & $\begin{array}{l}\text { Familial ET } \\
(\mathrm{n}=232)\end{array}$ & $\begin{array}{l}\text { Sporadic ET } \\
(\mathrm{n}=144)\end{array}$ & $\begin{array}{l}\text { All cases } \\
(\mathrm{n}=376)\end{array}$ \\
\hline $\begin{array}{l}\text { Current age, years } \\
\quad \text { Median }\end{array}$ & $66.6 \pm 15.8$ & $68.9 \pm 14.0$ & $67.5 \pm 15.1$ \\
$\begin{array}{l}\text { Female gender } \\
\text { Education, years }\end{array}$ & $124(53.4)$ & 71 & 71 \\
$\begin{array}{l}\text { Total tremor score* } \\
\begin{array}{l}\text { Tremor duration, years* } \\
\text { Age of tremor onset, }\end{array}\end{array}$ & $15.4 \pm 3.6$ & $14.7 \pm 4.1$ & $196(52.1)$ \\
$\quad$ years* & $39.1 \pm 22.2$ & $17.6 \pm 7.2$ & $18.1 \pm 3.8$ \\
$\begin{array}{l}\text { Currently taking } \\
\text { medication for }\end{array}$ & & $15.0 \pm 14.9$ & $22.8 \pm 18.7$ \\
$\quad$ tremor* & $139(59.9)$ & $65(45.1)$ & $204(54.3)$ \\
\hline
\end{tabular}

All values are means \pm standard deviations or proportions (percentages).

$* \mathrm{p}<0.05$ (familial ET vs. sporadic ET).

present and the severity of tremor that should be evident during these maneuvers to distinguish normal from ET. The WHIGET criteria have been shown to be both reliable [16] and valid [17], and have been used by tremor investigators in the United States and internationally [18-27].

\section{Definitions}

Familial ET $\left(\mathrm{ET}_{\mathrm{F}}\right)$ was defined using both liberal and conservative criteria. Using liberal criteria, $\mathrm{ET}_{\mathrm{F}}$ was found to denote the presence, by the proband's report, of at least one first- or seconddegree relative with 'ET' or 'tremor'; sporadic ET $\left(\mathrm{ET}_{\mathrm{S}}\right)$ was defined as the absence of at least one such relative. Using conservative criteria, $\mathrm{ET}_{\mathrm{F}}$ was the presence, by the proband's report, of at least one first- or second-degree relative with 'ET'; sporadic ET $\left(\mathrm{ET}_{\mathrm{S}}\right)$ was defined as the absence of at least one such relative.

\section{Analyses}

Analyses were initially performed using the liberal definition for $\mathrm{ET}_{\mathrm{F}}$ and then repeated using the conservative definition of ET. As in prior studies, childhood onset ET was defined as age 18 or younger [28]. As the age of onset was not normally distributed (Kolmogorov-Smirnov test, $\mathrm{p}$ value $<0.001$ ), a non-parametric test (Mann-Whitney test) was used when comparing groups by age of onset. Several of our analyses/tables also considered the current age, as current age and age of onset are highly correlated.

\section{Results}

There were 388 ET cases, of whom 376 (97\%) provided information on the age of onset and were included in the analysis (table 1). $\mathrm{ET}_{\mathrm{F}}$ was identified in $232(61.7 \%)$ cases using the liberal definition and $117(31.1 \%)$ cases using the conservative definition. The current age of $\mathrm{ET}_{\mathrm{F}}$ was 
Table 2. Age of onset by current age stratum in $\mathrm{ET}_{\mathrm{F}} \mathrm{vs} \mathrm{ET}_{\mathrm{S}}$

\begin{tabular}{|c|c|c|c|c|c|}
\hline $\begin{array}{l}\text { Current age } \\
\text { stratum, years }\end{array}$ & $\mathrm{n}$ & $\begin{array}{l}\text { Age of onset, } \\
\text { years }\left(\mathrm{ET}_{\mathrm{F}}\right)^{\mathrm{a}}\end{array}$ & $\mathrm{n}$ & $\begin{array}{l}\text { Age of onset, } \\
\text { years }\left(\mathrm{ET}_{\mathrm{S}}\right)^{\mathrm{a}}\end{array}$ & $\begin{array}{l}\text { Significance }{ }^{b} \\
\text { p value }\end{array}$ \\
\hline$<25$ & 4 & $8.5 \pm 2.4[8.5]$ & 1 & $16(n=1)$ & NA \\
\hline $25-29$ & 5 & $11.8 \pm 5.3[15.0]$ & 1 & $25(\mathrm{n}=1)$ & NA \\
\hline $30-34$ & 7 & $12.3 \pm 4.7[14.0]$ & 1 & $12(\mathrm{n}=1)$ & NA \\
\hline $35-39$ & 7 & $16.0 \pm 7.8[15.0]$ & 7 & $20.7 \pm 10.1[23.0]$ & 0.38 \\
\hline $40-44$ & 5 & $22.2 \pm 11.1[24.0]$ & 2 & $37.5 \pm 0.7[37.5]$ & 0.095 \\
\hline $45-49$ & 6 & $18.2 \pm 12.5[16.0]$ & 3 & $40.0 \pm 8.7[45.0]$ & 0.048 \\
\hline $50-54$ & 7 & $29.1 \pm 15.1[30.0]$ & 5 & $32.2 \pm 18.2[45.0]$ & 0.64 \\
\hline $55-59$ & 8 & $22.9 \pm 14.1[19.5]$ & 6 & $47.0 \pm 16.4[53.5]$ & 0.01 \\
\hline $60-64$ & 28 & $42.1 \pm 17.0[48.0]$ & 14 & $51.8 \pm 11.1[55.5]$ & 0.04 \\
\hline $65-69$ & 32 & $36.8 \pm 19.6[42.0]$ & 18 & $48.4 \pm 18.6[57.0]$ & 0.025 \\
\hline $70-74$ & 44 & $41.0 \pm 19.7[45.0]$ & 33 & $56.3 \pm 15.0[61.0]$ & $<0.001$ \\
\hline $75-79$ & 39 & $49.7 \pm 20.5[55.0]$ & 23 & $58.2 \pm 18.4[65.0]$ & 0.081 \\
\hline $80-84$ & 19 & $53.4 \pm 20.7[60.0]$ & 18 & $66.8 \pm 12.2[71.5]$ & 0.049 \\
\hline$\geq 85$ & 21 & $50.0 \pm 21.2[65.0]$ & 12 & $77.4 \pm 13.0[79.5]$ & 0.001 \\
\hline
\end{tabular}

a All values are means \pm standard deviations [medians]. ${ }^{\mathrm{b}}$ Mann-Whitney test comparing age of onset in $\mathrm{ET}_{\mathrm{F}}$ vs. $\mathrm{ET}_{\mathrm{S}} . \mathrm{NA}=$ Not applicable.

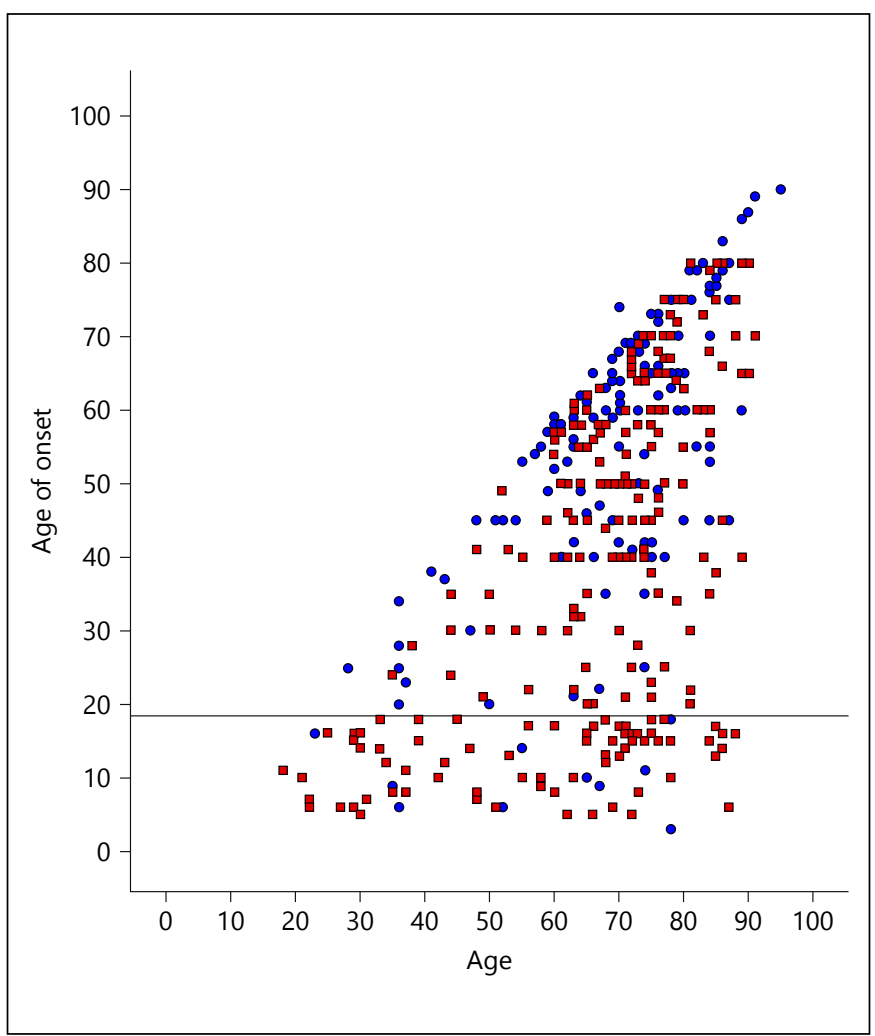

Fig. 1. Current age in years ( $\mathrm{x}$ axis) by age of onset in years ( $\mathrm{y}$ axis) in $\mathrm{ET}_{\mathrm{F}}$ (red squares) and $\mathrm{ET}_{\mathrm{S}}$ (blue circles). Childhood onset cases (age at onset $\leq 18$ years) appear below the horizontal line. similar to that of $\mathrm{ET}_{\mathrm{S}}$ : median $=71.0$ for $\mathrm{ET}_{\mathrm{F}}$ using liberal definition versus 71.0 for $\mathrm{ET}_{\mathrm{S}}$ (Mann-Whitney test $=1.24$, $\mathrm{p}=0.22)$, and median $=71.0$ for $\mathrm{ET}_{\mathrm{F}}$ using conservative definition versus 71.0 for $\mathrm{ET}_{\mathrm{S}}(\mathrm{Mann}-\mathrm{Whitney}$ test $=0.09$, $\mathrm{p}=0.93$ ).

We plotted age by the age at onset, comparing $\mathrm{ET}_{\mathrm{F}}$ (liberal definition) to $\mathrm{ET}_{\mathrm{S}}$ (fig. 1). Several patterns were evident:

(1) Overall, the age of onset of $\mathrm{ET}_{\mathrm{F}}$ cases was lower than that of $\mathrm{ET}_{\mathrm{S}}$ cases (i.e. note the downward shift in the distribution of red squares relative to blue circles in fig. 1). The mean \pm standard deviation age of onset was $39.1 \pm 22.2$ (median $=40.0$ years) for $\mathrm{ET}_{\mathrm{F}}$ vs. $53.9 \pm 19.8$ (59.0 years) for $\mathrm{ET}_{\mathrm{S}}$ (Mann-Whitney $\mathrm{z}=6.13, \mathrm{p}<0.001$ ).

(2) In general, at each current age, the mean age of onset of $\mathrm{ET}_{\mathrm{F}}$ cases was lower than that of $\mathrm{ET}_{\mathrm{S}}$ cases (table 2; fig. 2).

(3) Among all childhood onset (age of onset $\leq 18$ years, $\mathrm{n}=82)$ cases, $71(86.6 \%)$ had familial as opposed to sporadic ET (fig. 1; table 3).

(4) Childhood onset ET was not always familial - 11 (13.4\%) of 82 cases with onset $\leq 18$ years had $\mathrm{ET}_{\mathrm{S}}$ (fig. 1; table 3). Conversely, 11 (7.6\%) of $144 \mathrm{ET}_{\mathrm{S}}$ cases had an age of onset that was $\leq 18$ years.

(5) The age at onset was found to be $\geq 40$ years in majority of both familial $(54 \%, \mathrm{n}=125)$ and sporadic $(82 \%$, $\mathrm{n}=118$ ) cases (fig. 1 ; table 3 ).

(6) $\mathrm{ET}_{\mathrm{F}}$ seemed to have two peaks in the age of onset (see table 3 and two clusters of red squares in fig. 1): a childhood peak ( $\leq 18$ years) that comprised 71 (30.6\%) 


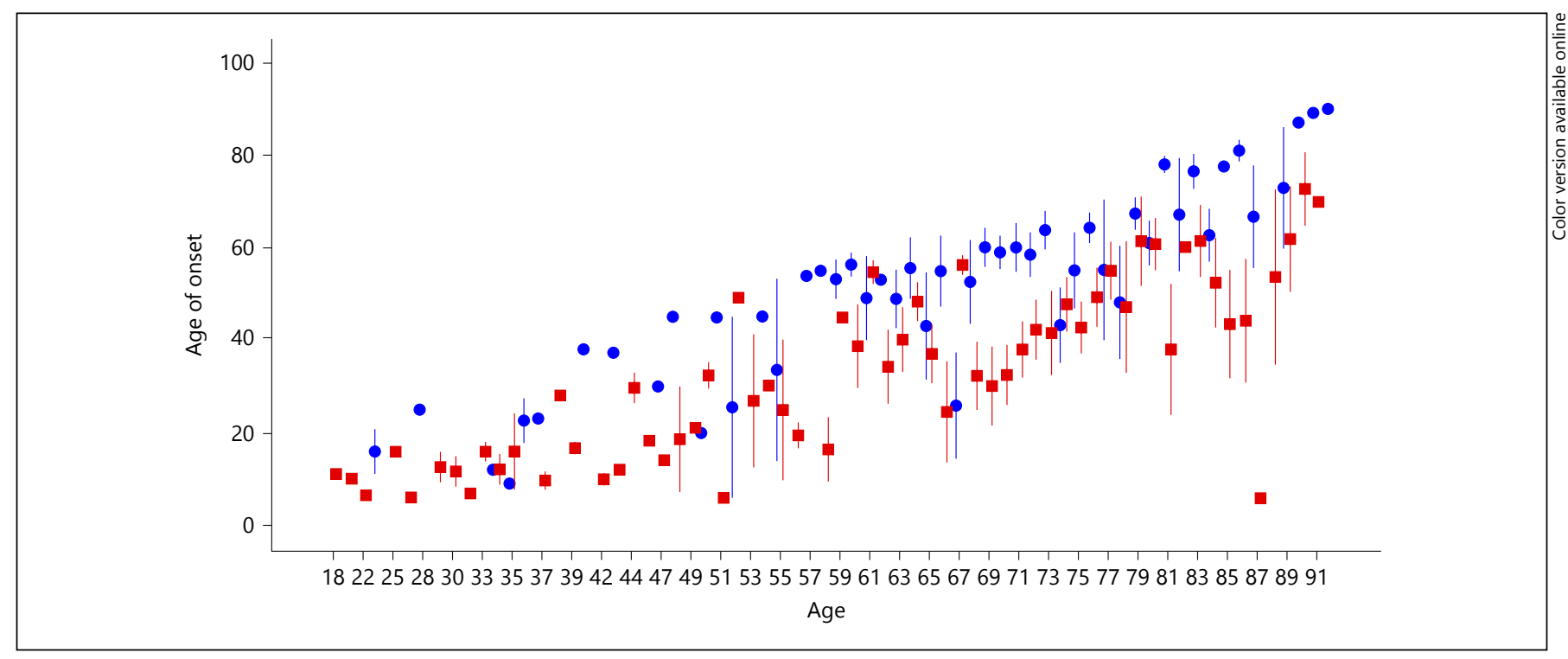

Fig. 2. Current age in years ( $\mathrm{x}$ axis) by age of onset in years (y axis) of $\mathrm{ET}_{\mathrm{F}}$ cases (red squares) versus $\mathrm{ET}_{\mathrm{S}}$ cases (blue circles). Circles and squares represent the mean age of onset at each current age and bars represent 1 standard error.

cases and an older peak ( $\geq 40$ years) that comprised 125 (53.9\%) cases (fig. 1). The remaining $36(15.5 \%)$ cases were between ages 19 and 39 .

(7) The age at onset was 60 years or older in a significant proportion of both familial $(22.8 \%, \mathrm{n}=53)$ and sporadic $(48.6 \%, \mathrm{n}=70)$ cases (fig. 1 ; table 3 ).

The findings using the conservative definition of $\mathrm{ET}_{\mathrm{F}}$ were similar to those presented earlier, with similar patterns as noted above in 1-7 (data not shown).

One possible explanation for apparently younger age at onset in familial ET is that $\mathrm{ET}_{\mathrm{F}}$ cases are more aware of their own tremor than are sporadic cases, because they have relatives with tremor. That is, even if the actual age at onset is the same in both groups, familial ET cases may report a younger age of onset because of greater awareness of their tremor. To explore this possibility, we performed a secondary analysis in which we stratified $\mathrm{ET}_{\mathrm{F}}$ cases into those who reported having affected relatives in preceding generations (e.g. grandparents, parents, aunts, or uncles) versus those who reported affected relatives only in the same or younger generations (e.g. siblings, children) (fig. 3). In general, at each current age, the age of onset of $\mathrm{ET}_{\mathrm{F}}$ cases in the latter group (with affected relatives only in the same or younger generations) remained lower than that of $\mathrm{ET}_{\mathrm{S}}$ cases (fig. 3). This suggests that the observed difference in the age of onset between $\mathrm{ET}_{\mathrm{F}}$ and $\mathrm{ET}_{\mathrm{S}}$ is not solely the result of reporting bias.

Familial versus Sporadic ET: Patterns in Age of Onset
Table 3. Number (proportion) of $\mathrm{ET}_{\mathrm{F}} \mathrm{vs}$. $\mathrm{ET}_{\mathrm{S}}$ cases in each age of onset stratum

\begin{tabular}{|c|c|c|}
\hline Age of onset stratum, years & $\mathrm{ET}_{\mathrm{F}}(\mathrm{n}=232)$ & $\mathrm{ET}_{\mathrm{S}}(\mathrm{n}=144)$ \\
\hline \multicolumn{3}{|l|}{ By 5-year age of onset stratum } \\
\hline$<5$ & $0(0.0)$ & $1(0.7)$ \\
\hline $5-9$ & $19(8.2)$ & $4(2.8)$ \\
\hline $10-14$ & $21(9.1)$ & $4(2.8)$ \\
\hline $15-18^{\mathrm{a}}$ & $31(13.4)$ & $2(1.4)$ \\
\hline $19-24^{\mathrm{a}}$ & $12(5.2)$ & $5(3.5)$ \\
\hline $25-29$ & $5(2.2)$ & $4(2.8)$ \\
\hline $30-34$ & $11(4.7)$ & $2(1.4)$ \\
\hline $35-39$ & $8(3.4)$ & $4(2.8)$ \\
\hline $40-44$ & $17(7.3)$ & $11(7.6)$ \\
\hline $45-49$ & $14(6.0)$ & $15(10.4)$ \\
\hline $50-54$ & $18(7.8)$ & $8(5.6)$ \\
\hline $55-59$ & $23(9.9)$ & $14(9.7)$ \\
\hline $60-64$ & $16(6.9)$ & $19(13.2)$ \\
\hline $65-69$ & $15(6.5)$ & $21(14.6)$ \\
\hline $70-74$ & $11(4.7)$ & $10(6.9)$ \\
\hline $75-79$ & $6(2.6)$ & $12(8.3)$ \\
\hline $80-84$ & $5(2.2)$ & $4(2.8)$ \\
\hline$\geq 85$ & $0(0.0)$ & $4(2.8)$ \\
\hline \multicolumn{3}{|l|}{ By larger age of onset stratum } \\
\hline$\leq 18$ & $71(30.6)$ & $11(7.6)$ \\
\hline 19-39 & $36(15.5)$ & $15(10.4)$ \\
\hline 40-59 & $72(31.0)$ & $48(33.3)$ \\
\hline$\geq 60$ & $53(22.8)$ & $70(48.6)$ \\
\hline
\end{tabular}

Percentages are column percentages.

a These two age strata were modified slightly in order to better present data for childhood onset ET (i.e. onset $\leq 18$ years). 


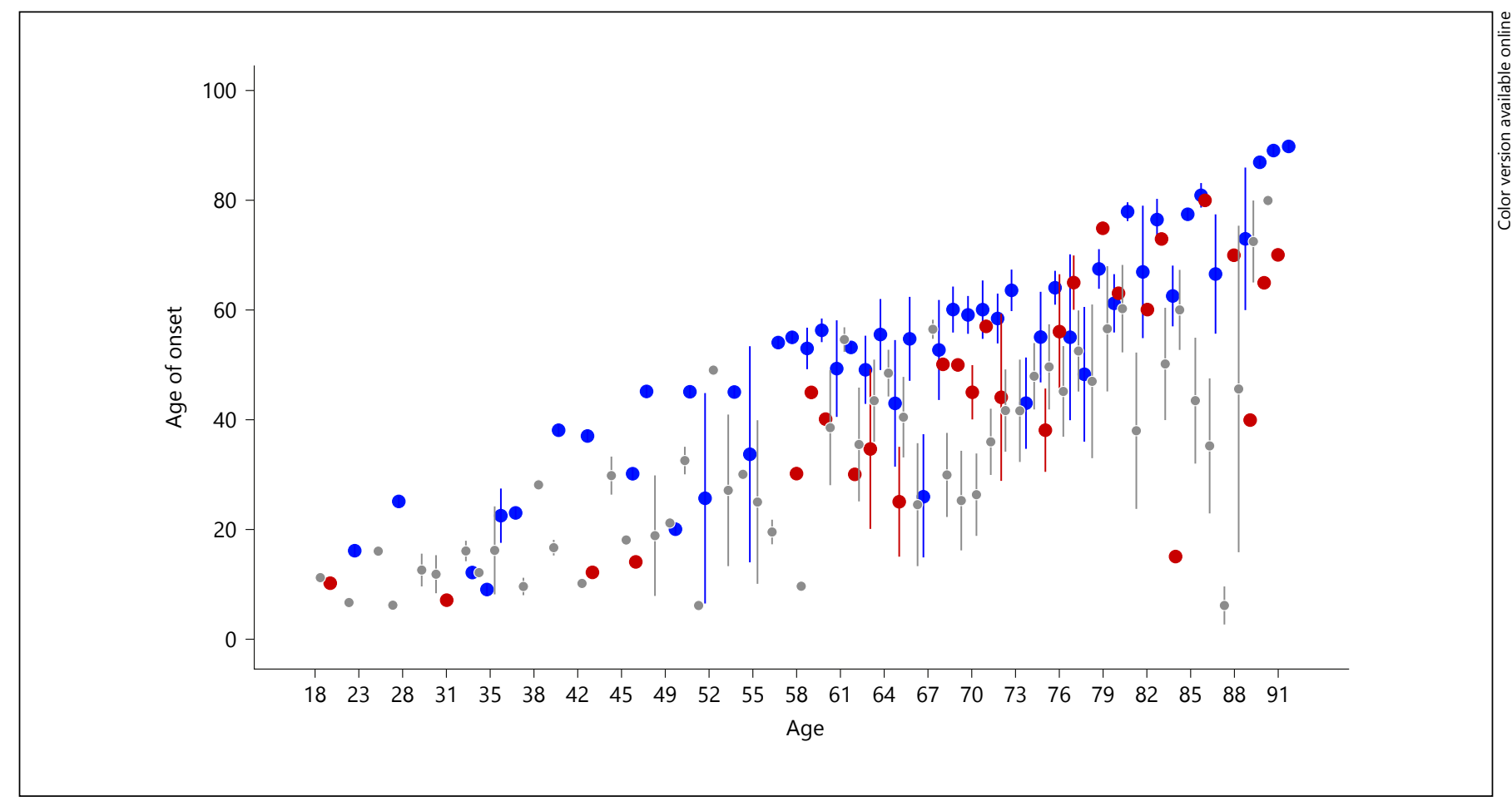

Fig. 3. Current age in years ( $\mathrm{x}$ axis) by age of onset in years (y axis). Red circles are $\mathrm{ET}_{\mathrm{F}}$ cases whose affected relatives are in the same generation or in a younger generation than the proband. Gray cir-

\section{Discussion}

Familial ET is widely believed to have an earlier age onset than sporadic ET, but no detailed analysis of the distributions of age of onset has been done. In this study, we found a number of patterns.

Age of onset varied widely within both forms of ET; however, in general, the age of onset of $\mathrm{ET}_{\mathrm{F}}$ cases was statistically significantly younger than that of $\mathrm{ET}_{\mathrm{S}}$ cases. $\mathrm{Cu}$ riously, childhood onset was rare in $\mathrm{ET}_{S}$ but was common in $\mathrm{ET}_{\mathrm{F}}$. Yet this dearth of childhood onset $\mathrm{ET}_{\mathrm{S}}$ cases did not account entirely for the observed younger age of onset of $\mathrm{ET}_{\mathrm{F}}$ cases than $\mathrm{ET}_{\mathrm{S}}$ cases. On closer inspection (fig. 2; table 2), one can see that at each current age, the age of onset of $\mathrm{ET}_{\mathrm{F}}$ cases was lower than that of $\mathrm{ET}_{\mathrm{S}}$ cases. Hence, having a genetic predisposition for ET not only increases disease risk [1], but it also seems to lower the age of disease onset.

In $\mathrm{ET}_{\mathrm{F}}$ but not $\mathrm{ET}_{\mathrm{S}}$, there seemed to be two peaks at the age of onset, a young peak and an older peak. In $\mathrm{ET}_{S}$, by contrast, while there were some young-onset cases, there was no young-onset peak. This suggests that the genetic predisposition results in an early onset form of disease cles are $\mathrm{ET}_{\mathrm{F}}$ cases whose affected relatives are in preceding generations. Blue circles are $\mathrm{ET}_{\mathrm{S}}$ cases. Circles represent means and each bar represents 1 standard error. during childhood. Thus, the genetic predisposition not only increases disease risk, and lowers age of onset at each age across the age spectrum, as discussed above, but it also results in a childhood onset form of the disease. Why some cases of $\mathrm{ET}_{\mathrm{F}}$ begin in childhood and some others do not begin until elderly life, is not clear, but could be related to the nature of the underlying susceptibility gene or genes as well as their combination with environmental factors.

A small number, 7.6\%, of $\mathrm{ET}_{\mathrm{S}}$ cases had childhood onset ET. These cases had no apparent family history. One explanation is that they did not correctly recall their age of onset, misattributing it to a younger age. Another explanation is that they may have had affected relatives about which they were unaware. Alternatively, they may have had a genetic form of ET, but had no affected relatives due to reduced penetrance or variable expressivity. A final possibility is that their disease was triggered by an early, unidentified environmental exposure or that the basis for the tremor, if genetic, was due to a de novo mutation.

Despite a younger age at onset distribution of $\mathrm{ET}_{\mathrm{F}}$, cases continued to arise even after age 60 ; indeed, these cas- 
es accounted for nearly 1 in $4 \mathrm{ET}_{\mathrm{F}}$ cases. These data suggest the presence of variable expressivity.

Overall, the data paint a picture of a disease for which, even in its familial form, there is a broad range of disease onset, with cases arising from the first decade of life all the way to the ninth decade. Hence, there seems to be an array of forces ranging from those that push onset at a very early age (i.e. even during early childhood) (e.g. rare highly penetrant mutations) to those whose influence on disease expression seems muted until advanced age ('uncommon' risk factors).

The current study had a number of limitations. First, our study utilized patients from a single cohort and it would be of value to extend these studies to additional cohorts. Second, in some cases, the age of onset can be misremembered, and so it is possible that some of our data on the age of onset lack precision. Third, we asked our cases to self-report the presence of a family history but did not examine their immediate or extended families. This, too, could have resulted in some misclassification of $\mathrm{ET}_{\mathrm{F}}$ as $\mathrm{ET}_{\mathrm{S}}$ and vice versa.

The study also had several strengths. First, the large sample of nearly $400 \mathrm{ET}$ cases provided sufficient clinical observations to be able to detect a range of clinical patterns. Second, all cases were diagnosed with ET using stringent research criteria. Third, we also considered in our analyses alternative definitions of $\mathrm{ET}_{\mathrm{F}}$.

In summary, the age of onset of $\mathrm{ET}$ differs between $\mathrm{ET}_{\mathrm{F}}$ and $\mathrm{ET}_{\mathrm{S}}$ and furthermore, is variable within each of these groups. Understanding the sources of this heterogeneity will provide some insight into the nature of underlying etiological and patho-biological processes, about which so little is presently known.

\section{Disclosure Statement}

The authors declare no competing financial interests.

\section{Funding/Acknowledgments}

Dr. Louis has received research support from the National Institutes of Health (NIH): NINDS \#R01 NS042859 (principal investigator), NINDS \#R01 NS39422 (principal investigator), NINDS \#R01 NS086736 (principal investigator), NINDS \#R01 NS073872 (principal investigator), NINDS \#R01 NS085136 (principal investigator), NINDS \#T32 NS07153-24 (principal investigator), NINDS \#R21 NS077094 (co-investigator), and NINDS \#R01 NS36630 (co-investigator). This funding body played no role in the design of the study, the collection, analysis, and interpretation of data, or the writing of the manuscript.

The statistical analyses were conducted by Elan D. Louis.

\section{References}

$\checkmark 1$ Louis ED, Ford B, Frucht S, Barnes LF, XTang M, Ottman R: Risk of tremor and impairment from tremor in relatives of patients with essential tremor: a communitybased family study. Ann Neurol 2001;49: 761-769.

-2 Louis ED, Ottman R: How familial is familial tremor? The genetic epidemiology of essential tremor. Neurology 1996;46:1200-1205.

3 Deng H, Le W, Jankovic J: Genetics of essential tremor. Brain 2007;130:1456-1464.

-4 Tan EK, Schapira AH: Hunting for genes in essential tremor. Eur J Neurol 2008; 15:889890.

5 Scarmeas N, Louis ED: Mediterranean diet and essential tremor. A case-control study. Neuroepidemiology 2007;29:170-177.

6 Louis ED: Environmental epidemiology of essential tremor. Neuroepidemiology 2008;31: 139-149.

-7 Jiménez-Jiménez FJ, de Toledo-Heras $M$, Alonso-Navarro H, Ayuso-Peralta L, Arévalo-Serrano J, Ballesteros-Barranco A, Puertas I, Jabbour-Wadih T, Barcenilla B: Environmental risk factors for essential tremor. Eur Neurol 2007;58:106-113.

8 Louis ED, Factor-Litvak P, Liu X, Vonsattel JP, Galecki M, Jiang W, Zheng W: Elevated brain harmane (1-methyl-9H-pyrido[3,4-b] indole) in essential tremor cases vs. controls. Neurotoxicology 2013;38:131-135.

-9 Tanner CM, Goldman SM, Lyons KE, Aston DA, Tetrud JW, Welsh MD, Langston JW, Koller WC: Essential tremor in twins: an assessment of genetic vs environmental determinants of etiology. Neurology 2001;57: 1389-1391.

10 Louis ED, Dogu O: Does age of onset in essential tremor have a bimodal distribution? Data from a tertiary referral setting and a population-based study. Neuroepidemiology 2007;29:208-212.

11 Louis ED, Ottman R: Study of possible factors associated with age of onset in essential tremor. Mov Disord 2006;21:1980-1986.

12 Brin MF, Koller W: Epidemiology and genetics of essential tremor. Mov Disord 1998; 13(suppl 3):55-63.

13 Louis ED, Gerbin M, Galecki M: Essential tremor 10, 20, 30, 40: clinical snapshots of the disease by decade of duration. Eur J Neurol 2013;20:949-954.

14 Louis ED: When do essential tremor patients develop head tremor? Influences of age and duration and evidence of a biological clock. Neuroepidemiology 2013;41:110-115.
15 Louis ED, Schonberger RB, Parides M, Ford B, Barnes LF: Test-retest reliability of patient information on age of onset in essential tremor. Mov Disord 2000;15:738-741.

16 Louis ED, Ford B, Bismuth B: Reliability between two observers using a protocol for diagnosing essential tremor. Mov Disord 1998; 13:287-293.

17 Louis ED, Pullman SL: Comparison of clinical vs. electrophysiological methods of diagnosing of essential tremor. Mov Disord 2001;16: 668-673.

18 Dogu O, Sevim S, Camdeviren H, Sasmaz T, Bugdayci R, Aral M, Kaleagasi H, Un S, Louis ED: Prevalence of essential tremor: door-to-door neurologic exams in Mersin Province, Turkey. Neurology 2003;61:18041806.

19 Inzelberg R, Mazarib A, Masarwa M, Abuful A, Strugatsky R, Friedland RF: Essential tremor prevalence is low in Arabic villages in Israel: door-to-door neurological examinations. J Neurol 2006;253:15571560.

20 Gasparini M, Bonifati V, Fabrizio E, Fabbrini G, Brusa L, Lenzi GL, Meco G: Frontal lobe dysfunction in essential tremor: a preliminary study. J Neurol 2001;248:399-402.
Familial versus Sporadic ET: Patterns in Age of Onset
Neuroepidemiology 2015;44:166-172 DOI: $10.1159 / 000381807$ 
21 Farrer $\mathrm{M}$, Gwinn-Hardy K, Muenter $\mathrm{M}$, DeVrieze FW, Crook R, Perez-Tur J, Lincoln S, Maraganore D, Adler C, Newman S, Mac Elwee K, McCarthy P, Miller C, Waters C, Hardy J: A chromosome 4p haplotype segregating with Parkinson's disease and postural tremor. Hum Mol Genet 1999;8:81-85.

22 Dogu O, Sevim S, Louis ED, Kaleagasi H, Aral M: Reduced body mass index in patients with essential tremor: a population-based study in the province of Mersin, Turkey. Arch Neurol 2004;61:386-389.

23 Gatto EM, Roca MC, Raina G, Micheli F: Low doses of topiramate are effective in essential tremor: a report of three cases. Clin Neuropharmacol 2003;26:294-296.

24 Benito-León J, Alvarez-Linera J, HernándezTamames JA, Alonso-Navarro H, JiménezJiménez FJ, Louis ED: Brain structural changes in essential tremor: voxel-based morphometry at 3-Tesla. J Neurol Sci 2009;287: 138-142.

25 Putzke JD, Uitti RJ, Obwegeser AA, Wszolek ZK, Wharen RE: Bilateral thalamic deep brain stimulation: midline tremor control. J Neurol Neurosurg Psychiatry 2005;76:684-690.

26 Obwegeser AA, Uitti RJ, Turk MF, Strongosky AJ, Wharen RE: Thalamic stimulation for the treatment of midline tremors in essential tremor patients. Neurology 2000;54: 2342-2344.

27 Seijo-Martínez M, Del Río MC, Alvarez JR, Prado RS, Salgado ET, Esquete JP, SobridoGómez MJ: Prevalence of essential tremor on Arosa Island, Spain: a communitybased, door-to-door survey. Tremor Other Hyperkinet Mov (N Y) 2013;3:tre-03-1924299-1.

28 Louis ED, Fernandez-Alvarez E, Dure LS 4th, Frucht S, Ford B: Association between male gender and pediatric essential tremor. Mov Disord 2005;20:904-906. 